\title{
THE SUNET SYSTEM FOR MONITORING NOISE POLLUTION IN CLUJ-NAPOCA
}

Ilinca Mirela Beca, Lecturer dr. eng., Technical University of Cluj-Napoca, Faculty of Civil Engineering, e-mail: ilinca.beca@cfdp.utcluj.ro

Mihai Iliescu, Professor dr. eng., Technical University of Cluj-Napoca, Faculty of Civil Engineering, e-mail: mihai.iliescu@cfdp.utcluj.ro

\section{Rezumat}

Preocupările autorităţilor locale din spaţiul european pentru a îmbunătăţi calitatea vieţii în spaţiul urban au condus la adoptarea Directivei Europene 49/2002 privind evaluarea şi gestionarea zgomotului ambiental prin întocmirea unor hărţi strategice de zgomot. Chiar dacă pentru aceste hărţi nu se impune o monitorizare continuă, autorităţile naţionale şi locale trebuie să aplice planuri de acţiune astfel încât să răspundă la o situaţie actuală în ceea ce priveşte gradul de expunere a populaţiei la un nivel ridicat de poluare fonică.

Platforma SUNET (System for Urban Noise and Eco-Traffic) a fost concepută pentru o mai bună gestionare a poluării fonice din municipiul Cluj-Napoca dar şi ca să ofere informaţii cu caracter public actualizate, pe o interfaţă online uşor de utilizat. Implementarea acestei aplicaţii pentru întreg municipiul Cluj-Napoca conduce la un sistem de legatură şi comunicare dinamic între administrator (Primăria Municipiului Cluj-Napoca) şi utilizator (cetăţeni), respectând cerinţele directivei europene.

\section{Cuvinte cheie: zgomot, poluare, urban, trafic, platformă}

\section{Abstract}

In Europe the need for local authorities to provide a high standard of living for their communities led to the establishment of the European noise mapping directive 2002/49/EC. Whilst Noise mapping itself doesn't need continuous noise monitoring, states must produce a noise action plan which highlights actions they intend to take to reduce the number of people affected.

SUNET platform (System for Urban Noise and Eco-Traffic) was designed for improved management of the noise pollution in Cluj-Napoca and to provide up-to-date public data on a user-friendly interface. The implementation of the application over the entire municipality is highly advantageous for it creates a link between the town's administration (the local authorities, the City Hall of Cluj-Napoca) and the user (the citizens) through this system which is dynamic, modern and compliant with the European regulations.

Keywords: noise, pollution, urban, traffic, system 


\section{THE ISSUE OF NOISE}

Within today's civilization, people live in an environment where they are constantly surrounded by noise and vibrations with a direct impact on their comfort and even their health. The continuous deterioration of the sound environment constitutes a characteristic of the modern habitat, whereas noise, and traffic noise in particular, constitutes a major source of stress and discomfort, particularly in the urban areas [3]. Noise pollution represents a major global problem, whereas the control and reduction of noise levels are identified as the new challenges of the $21^{\text {st }}$ century, particularly in the urban areas.

Spatial and urban planning constitute a powerful instrument in the prevention of noise pollution within the context of urban space planning [5]. More durable urban models can be developed and therefore, noise pollution can be reduced by the appropriate distribution of the available space, appropriate sizing of the transport infrastructure and the development of public transportation systems [5].

Directive 2002/499/EC of the European Parliament and of the Council of 06/25/2002 should provide a foundation for the development and complementation of the existing community measures regarding the noise generated by main sources, and by road and railway vehicles and their corresponding infrastructures in particular, as well as for the development of additional short, medium and long-term measures [2].

\subsection{The noise management system}

Romanian noise policy and legal context have developed significantly over recent years, in their attempt to integrate the most current issues. An integrated approach could include support and security by local operators for improved regional management purposes. Similarly, an efficient noise management system requires the completion of a number of stages, as presented in Figure 1. Cost efficiency is dependent on a vision on noise policy that integrates all sources [1].

Noise reduction measures can only be formulated within the overall context of road management. The legal priorities regarding noise reduction must be analyzed in association with other factors such as speed, safety, air quality, energy consumption, public transportation, the comfort of cyclists and pedestrians and interruptions of the traffic flow [4]. 


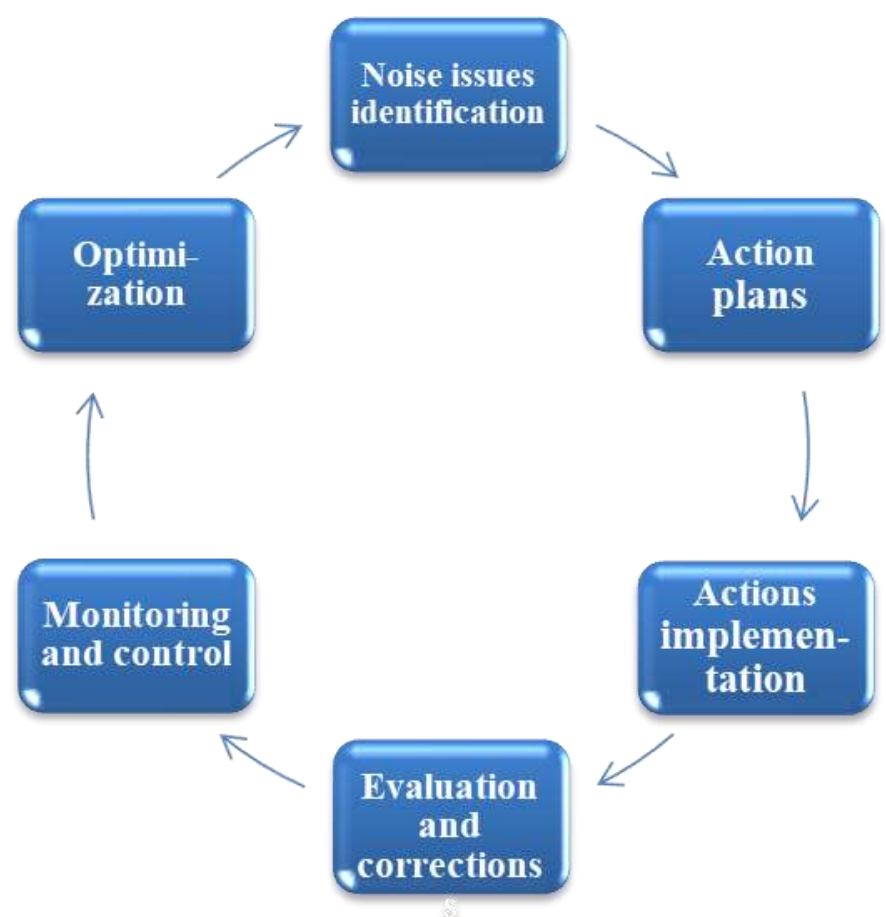

Figure 1. The interdependent relationship between the stages of noise reduction management

Therefore, the context shaped by all the above-mentioned considerations requires an approach based on a number of different criteria that assesses the effectiveness and opportunities provided by every potential noise reduction solution in the context of each road segment and its corresponding environment in order for the best results to be achieved using the available resources.

\subsection{The need for a noise monitoring system}

The SUNET (System for Urban Noise and Eco-Traffic) system was designed to monitor the noise pollution in Cluj-Napoca, as well as provide public, up-to-date information regarding the noise levels registered across the street network of the city.

Compliant with Directive 2002/49/EC, the system aims to provide a foundation for the development and complementation of the existing community measures regarding the noise generated by main sources, and by road vehicles in particular.

As far as the formulation and implementation of efficient action plans are concerned, the local authorities need the support of partners, particularly on a local level, as well as that of national authorities, particularly from a legal point 
of view. Urban noise management involves both the administrative and decisional structures of a city (internal structures) and the users (external structures). Tables 1 and 2 show the internal and external structures involved in this process, their relevance, as well as the types of actions that can be undertaken by these structures, thereby setting the foundations of efficient urban noise monitoring and management.

Table 1. The internal structures involved in noise management [1]

\begin{tabular}{|c|c|c|}
\hline Structure il & $\begin{array}{l}\begin{array}{l}\text { Relevance of the } \\
\text { structure }\end{array} \\
\end{array}$ & Actions to be undertaken \\
\hline $\begin{array}{c}\text { Public } \\
\text { administration }\end{array}$ & $\begin{array}{l}\text { It ensures the level of } \\
\text { competence required for } \\
\text { the implementation of } \\
\text { measures. }\end{array}$ & insportation \\
\hline $\begin{array}{r}\text { Transpo } \\
\text { plan } \\
\text { Road mai }\end{array}$ & $\begin{array}{l}\text { Transportation planning } \\
\text { impacts the management } \\
\text { of noise levels, but can } \\
\text { also affect the traffic flow }\end{array}$ & $\begin{array}{l}\text { To assess the potential noise } \\
\text { reduction measures, as well } \\
\text { as their impact on traffic }\end{array}$ \\
\hline $\begin{array}{l}\text { Urban pla } \\
\text { Spatial pla }\end{array}$ & $\begin{array}{l}\text { s the functional } \\
\text { e city }\end{array}$ & $\begin{array}{l}\text { To implement the action } \\
\text { plans; } \\
\text { To set goals }\end{array}$ \\
\hline Heal & $\begin{array}{l}\text { to noise has a } \\
\text { mpact on health }\end{array}$ & $\begin{array}{l}\text { To draw the attention of the } \\
\text { population on the negative } \\
\text { effects of exposure to noise }\end{array}$ \\
\hline $\begin{array}{r}\mathrm{U} \\
\text { rege }\end{array}$ & $\begin{array}{l}\text { It ensures the exploitation } \\
\text { of road planning/re- } \\
\text { planning opportunities to } \\
\text { achieve performance and } \\
\text { noise reduction }\end{array}$ & $\begin{array}{l}\text { To provide information } \\
\text { regarding the urban areas to } \\
\text { be subjected to restructuring; } \\
\text { To address the issue of noise } \\
\text { as a factor in road } \\
\text { restructuring }\end{array}$ \\
\hline Communication & $\begin{array}{l}\text { It ensures the sen- } \\
\text { sitization of public } \\
\text { opinion/efficient } \\
\text { communication strategies } \\
\text { It ensures the information } \\
\text { and consultation of } \\
\text { citizens as per the END }\end{array}$ & $\begin{array}{l}\text { To support the development } \\
\text { of an advanced public } \\
\text { consultation system } \\
\text { To develop informational } \\
\text { materials: } \\
\text { brochures, etc. websites, }\end{array}$ \\
\hline Local pe & $\begin{array}{l}\text { It ensures the level of } \\
\text { competence required for }\end{array}$ & $\begin{array}{l}\text { To implement } \\
\text { limitations and }\end{array}$ \\
\hline
\end{tabular}


ROMANIAN JOURNAL

OF TRANSPORT INFRASTRUCTURE

\begin{tabular}{|c|l|l|}
\hline & $\begin{array}{l}\text { the implementation of restrictions } \\
\text { speed limitations, traffic } \\
\text { restrictions, etc. }\end{array}$ & $\begin{array}{l}\text { To verify noise emission } \\
\text { levels for vehicles in general } \\
\text { and motorcycles in particular }\end{array}$ \\
\hline \multirow{3}{*}{ Environment } & $\begin{array}{l}\text { It ensures the level of } \\
\text { competence required to } \\
\text { deal with the numerous } \\
\text { synergies be-tween air } \\
\text { pollution and noise } \\
\text { pollution management }\end{array}$ & $\begin{array}{l}\text { To use the common databases } \\
\text { and software designed for air } \\
\text { pollution and noise pollution } \\
\text { management purposes }\end{array}$ \\
\hline
\end{tabular}

Transportation planning, urban planning and urban management should integrate an active approach toward the improvement of the urban noise landscape. The END requirements include the preparation of action plans. Detailed urban planning can provide a fine understanding of a town, whereas these actions generate improvements that reflect the local needs in a relevant manner and can be implemented in sustainable ways [4].

Table 2. The external structures involved in noise management [1]

\begin{tabular}{|c|c|c|}
\hline Structure involved & $\begin{array}{l}\text { Relevance of the } \\
\text { structure }\end{array}$ & Actions to be undertaken \\
\hline $\begin{array}{c}\text { Public } \\
\text { transportation }\end{array}$ & $\begin{array}{l}\text { - It represents a dominant } \\
\text { source of noise } \\
\text { - Modern public trans- } \\
\text { portation can provide a } \\
\text { quieter alternative to } \\
\text { personal vehicles }\end{array}$ & $\begin{array}{l}\text { - Car parks and trans- } \\
\text { portation infrastructure to } \\
\text { be adapted by public } \\
\text { transportation operators to } \\
\text { use technologies pro- } \\
\text { ducing reduced levels of } \\
\text { noise pollution } \\
\text { - To implement measures } \\
\text { that encourage the use of } \\
\text { public transportation }\end{array}$ \\
\hline $\begin{array}{l}\text { Regional or } \\
\text { national road } \\
\text { operators }\end{array}$ & $\begin{array}{l}\text {-They are responsible for } \\
\text { conducting road and traffic } \\
\text { studies on a constant basis }\end{array}$ & $\begin{array}{l}\text { - To collaborate with local } \\
\text { authorities and provide } \\
\text { traffic data required for } \\
\text { noise predictions }\end{array}$ \\
\hline $\begin{array}{c}\text { Private } \\
\text { transportation }\end{array}$ & $\begin{array}{l}\text {-The noise levels produced } \\
\text { by vehicles registered with } \\
\text { private transportation }\end{array}$ & $\begin{array}{l}\text { - To use vehicles in a good } \\
\text { technical condition that } \\
\text { produce lower noise levels }\end{array}$ \\
\hline
\end{tabular}


ROMANIAN JOURNAL

OF TRANSPORT INFRASTRUCTURE

Ilinca Mirela BECA, Mihai ILIESCU

The SUNET system for monitoring noise pollution in Cluj-Napoca

\begin{tabular}{|l|l|l|}
\hline companies & $\begin{array}{l}\text { companies exceed those } \\
\text { produced by regular } \\
\text { vehicles by approximately } \\
6 \text { decibels }\end{array}$ & $\begin{array}{l}\text {-To comply with time and } \\
\text { area restrictions } \\
\text {-To invest in heavy } \\
\text { vehicles that produce lower } \\
\text { noise levels and thereby in } \\
\text { the modernization of car } \\
\text { parks }\end{array}$ \\
\hline Citizens & $\begin{array}{l}\text { Collaboration with the } \\
\text { citizens is essential in the } \\
\text { accurate assessment of } \\
\text { noise pollution conflicts } \\
\text { The behavior of drivers } \\
\text { and road education can } \\
\text { contribute to the reduction } \\
\text { of noise pollution }\end{array}$ & $\begin{array}{l}\text { implications of loud driving } \\
\text { and of concepts such as } \\
\text { ecodriving } \\
\text {-To ensure road education } \\
\text { by complying with speed } \\
\text { limitations and restrictions } \\
- \text {-To encourage citizens to } \\
\text { use quieter or even hybrid } \\
\text { personal vehicles }\end{array}$ \\
\hline
\end{tabular}

\section{THE SUNET NOISE MONITORING SYSTEM}

The SUNET system is hosted by a web domain and can be accessed via the worldwide web at www.sunet.beca.ro. The application was developed upon conducting an extended study on the main traffic arteries of Cluj-Napoca using resources and equipment provided by the Traffic Engineering Department within the Faculty of Civil Engineering.

The system menu (Figure 2) has a user-friendly interface and consists of six functional sections, as follows:

- the homepage (Home);

- the monitoring application (Noise Monitoring);

- the simulation application (Route Simulator);

- the information page (Useful Info);

- the interactive page (FAQ);

- the contact page (Contact). 


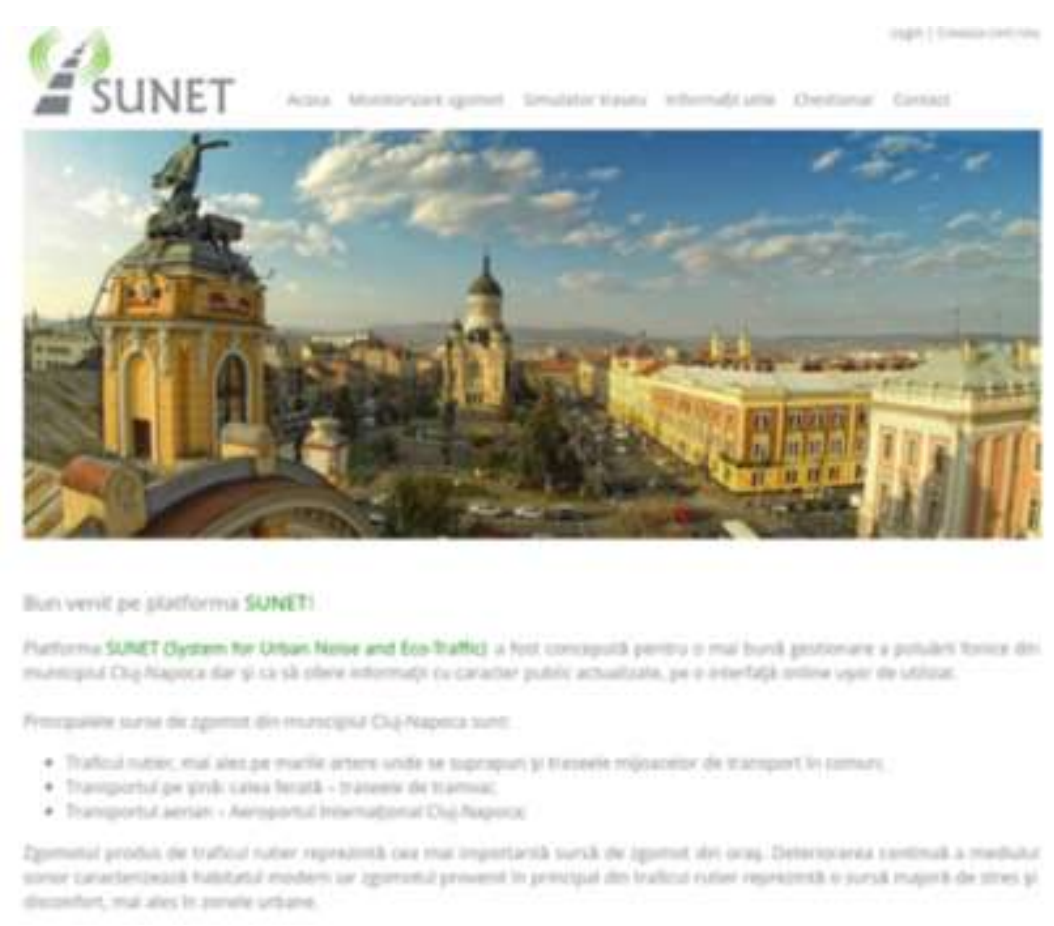

Figure 2. The SUNET interface

\subsection{The design of the database and software technology}

Data management is performed using a username and password protected CMS (Content Management System), the data being uploaded into the database from CSV (Comma Separated Values) files. The graphic interface uses the most frequently encountered web programming and interface design technology, i.e. the HTML language.

The database is set up in an SQL format, contains details about the system and user characteristics, which are organized into specific tables, and can manage over ten million entries.

The attribute tables corresponding to a Street entity are described by traffic, noise, geometrical characteristics and specific actions, as follows:

- Name of the street (street name dictionary of Cluj-Napoca);

- Type (classification of the streets in the urban area depending on the traffic volume);

- Category (classification of the streets depending on their importance);

- Traffic intensity (classification of the streets depending on the traffic intensity);

- Traffic volume (i.e. the number of vehicles running over a 24-hour period); 
- Traffic composition (i.e. heavy traffic, light traffic, public transportation, cyclists);

- Geometry of the street (the directions and number of lanes);

- Day noise levels ( $\mathrm{L}_{\mathrm{den}}$ values, measured in $\mathrm{dB}(\mathrm{A})$ );

- Night noise levels ( $\mathrm{L}_{\text {night }}$, measured in $\mathrm{dB}(\mathrm{A})$ );

- Completed action plans (description of the action plans implemented on the street up to a given time);

- Action plans in progress (description of the action plans proposed for future implementation on the street).

\subsection{Noise pollution monitoring}

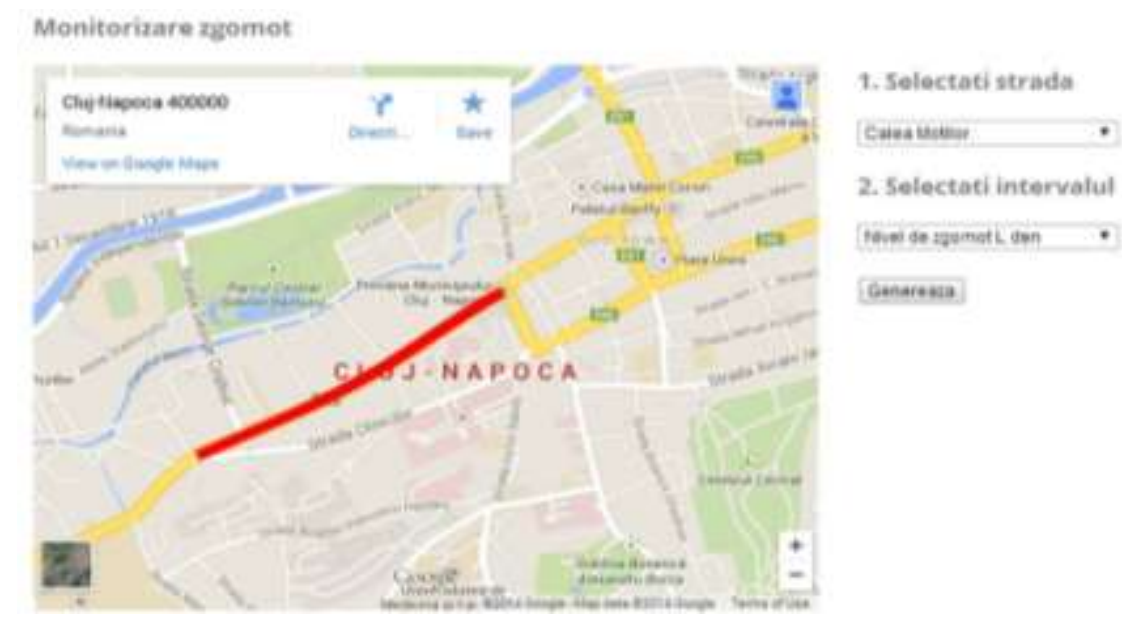

Figure 3. Database interrogation under Noise Monitoring [1]

The most complex section of the system is Noise Monitoring. This section uses the largest amount of resources in the database, which are organized around an interactive map of Cluj-Napoca.

The Map display mode is based on the Google Maps mapping software. The user can interrogate the database by selecting the Street and Time Slot parameters (Figure 3.). The captions consisting of the symbols used to display the results of the monitoring and simulation interrogation. Once the user's requests have been defined, graphic results (street markers), symbol results and content results (i.e. characteristics of the street and action plans) (Figure 4) generated by the application are displayed on the map, as described in subchapter 2.1. 


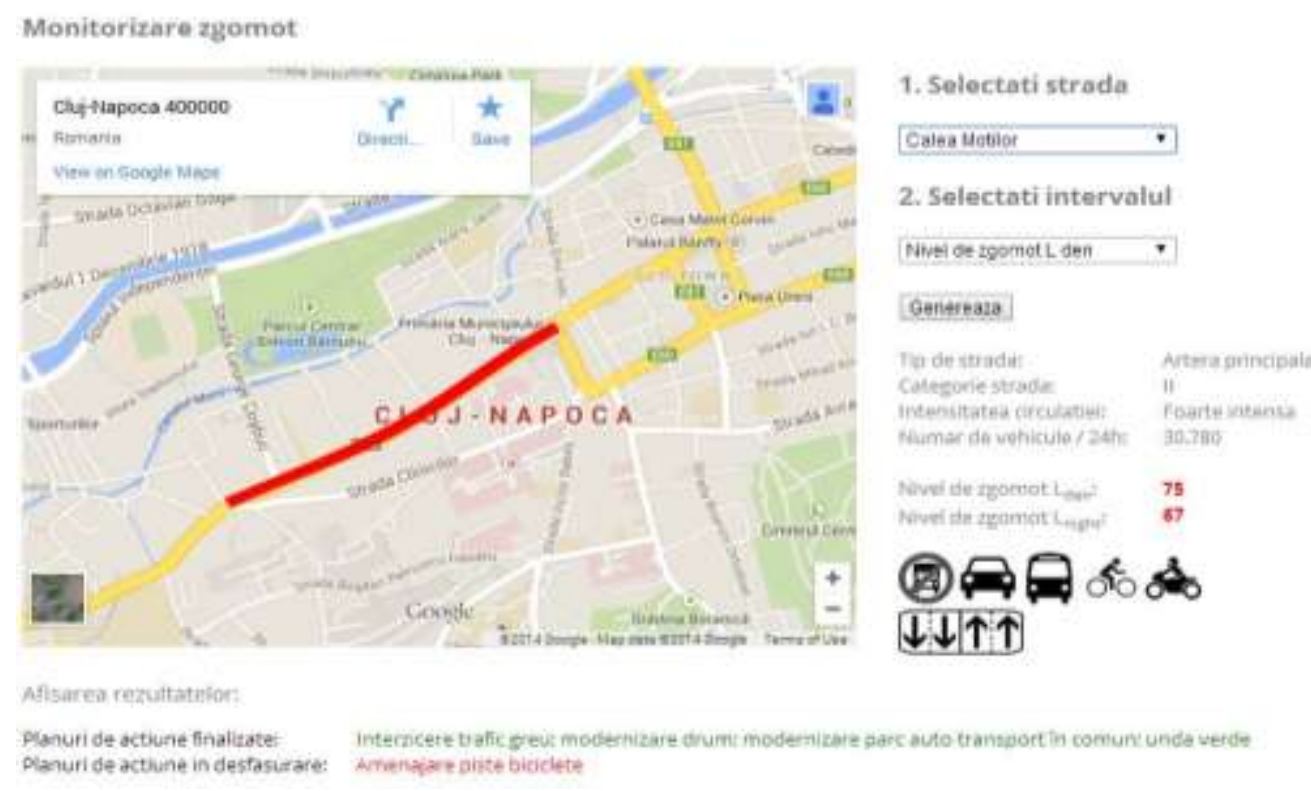

Figure 4. Results displayed under Noise Monitoring [1]

\subsection{Additional functions}

The Route Simulator function crosses Google Maps data with attributes of the SUNET database and generates routes depending on a selected means of transportation (i.e. monitored vehicle or bicycle). The results are displayed as a recommended route, which involves minimum exposure to noise pollution, or a fast route within the selected time slot (Figure 5).

A short description of the applicable law and the noise assessment methodology regarding urban traffic can be found in the Useful Info section (Figure 6). General information regarding the legal context, risks or effects of exposure to this type of pollution, among others, can also be found in this section. 


\section{ROMANIAN JOURNAL OF TRANSPORT INFRASTRUCTURE}

Ilinca Mirela BECA, Mihai ILIESCU

The SUNET system for monitoring noise pollution in Cluj-Napoca

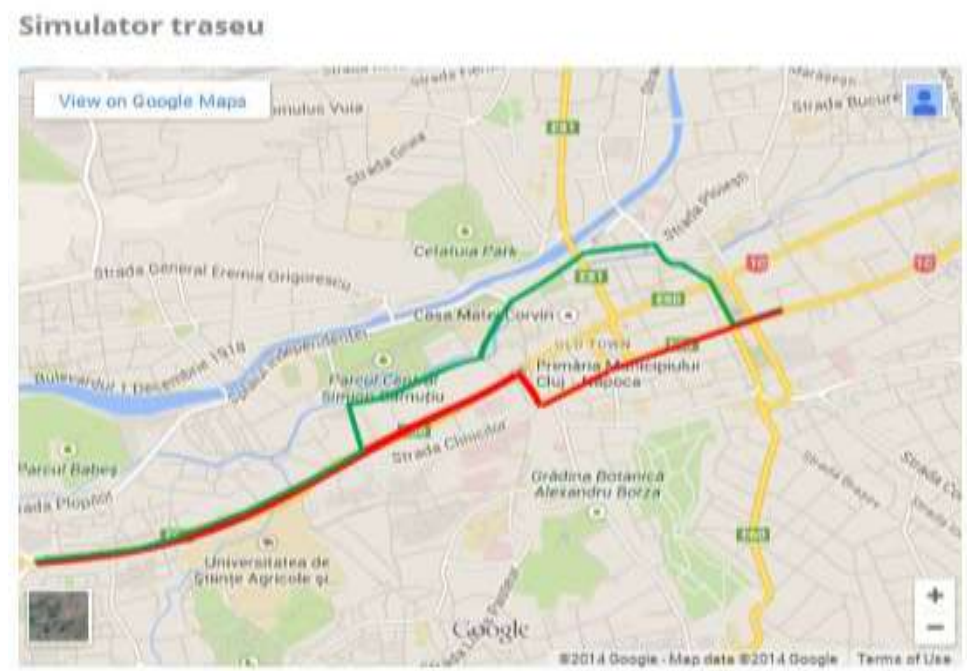

1. Selectati strada de plecare

Calea Manasur *

2. Selectati strada de sosire

Calea Dorobantilor *

3. Modul de transport:

Cu masina *

Genereaza traneu

Nivel maxim de expunere la zgomot:

Caloa Manastur - 76 da

Nivel minim de expunere la zyomot: Str Petru Maior - 68 de

\section{Afisarea rezultatelor:}

Va recomandam folosirea urmatorulul traseu:

Calea Manastur - Calea Motllor - 5tr George Cosbuc - Str Cardinal lullu Hossu - 5tr George Baritiu - Pta Mihal viteazu - Str Cuza Voda - Pta Avram Iancu - Bd Eroilor - Calea Dorobantilor

Figure 5. Routes generated under Route Simulator
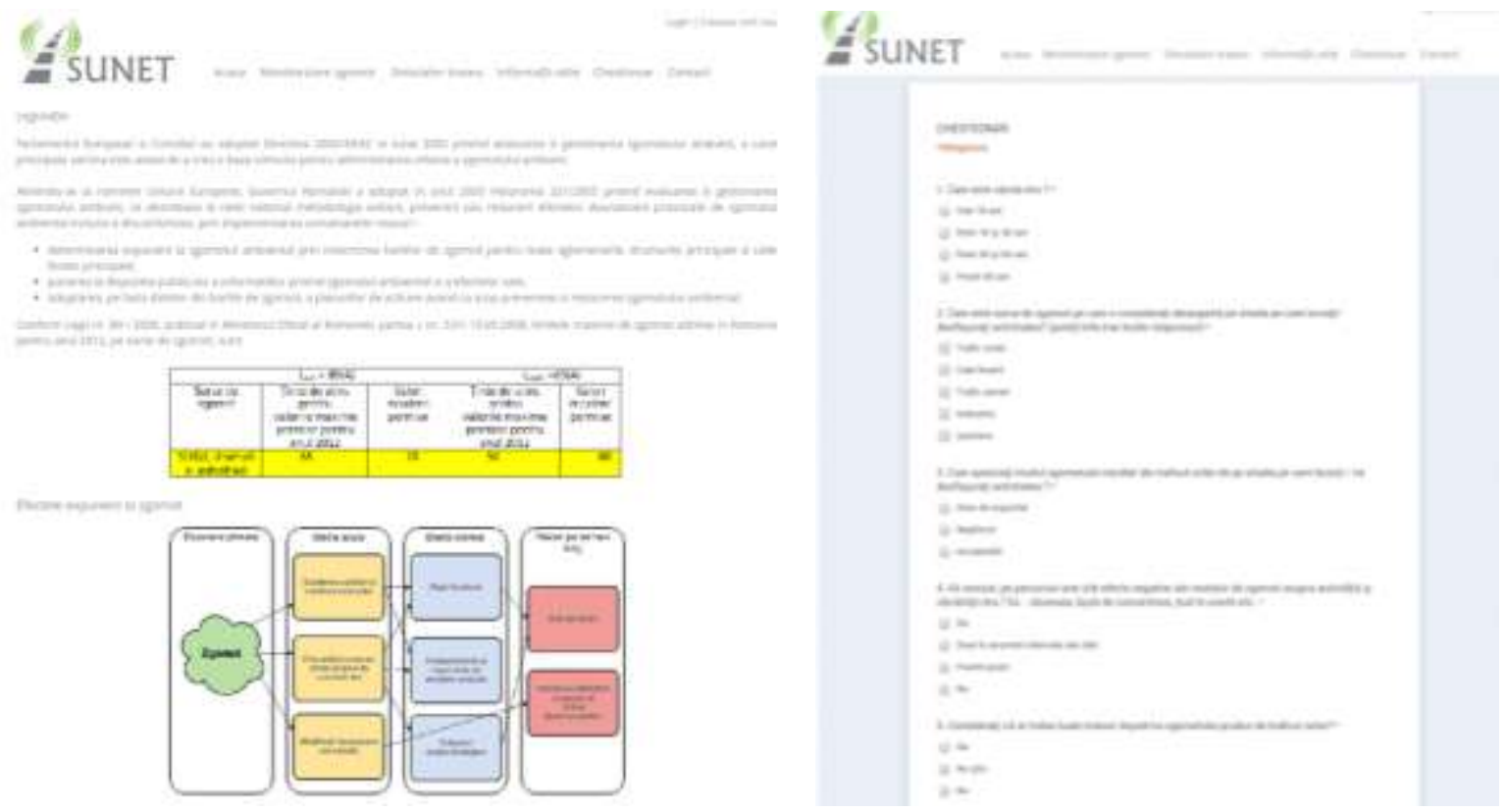

Figure 6. The Useful Info and Contact sections

An interactive page is also available to users, allowing them to contribute to the debates, strategies and decisions by the public administration. Through the 


\section{ROMANIAN JOURNAL OF TRANSPORT INFRASTRUCTURE}

administrative body, the internal structure focuses on the sensitization of public opinion as far as noise pollution is concerned, which requires an effective communication strategy [1]. The online questionnaire allows an assessment of the level of understanding of citizens, as well as that of the levels of discomfort, sources of noise or action plans implemented across the city streets (Figure 6).

\section{CONCLUSIONS}

All developed and developing countries pursue the development of a quiet urban environment. The participation in the decision-making process of communities is dependent on their awareness and access to means of communication adapted to the social context [1].

The need for an online urban noise monitoring system such as SUNET appears to allow the provision of fairly realistic and up-to-date information and encourage the community to actively assist in the implementation of proper action plans, as well as the decision-making process as far as exposure of the population to high levels of noise pollution is concerned [1].

The setup of this system as a database that integrates the entire street network of the city requires significant funding. A system that is managed and updated on a constant basis reflects a situation that is very close to the real one, protects the users from the implementation of unrealistic and inappropriate action plans, as well as ensures the use of the funding invested in research and implementation to achieve favorable results and thus an improved quality of life in urban areas.

\section{REFERENCES}

[1]. I.M. BECA: "Contributions on the implementation of complex noise pollution monitoring systems in the context of urban traffic development", Doctoral Thesis, Cluj-Napoca, 2014.

[2]. "Directive 2002/49/EC of the European Parliament and of the Council of 25 June 2002 relating to the assessment and management of environmental noise" Declaration by the Commission in the Conciliation Committee on the Directive relating to the assessment and management of environmental noise, Official Journal L 189, 18/07/2002 P.0012 - 0026, 2002. 


\section{ROMANIAN JOURNAL \\ OF TRANSPORT INFRASTRUCTURE}

Ilinca Mirela BECA, Mihai ILIESCU

The SUNET system for monitoring noise pollution in Cluj-Napoca

ambiant”, Monitorul Oficial no. 19/10 I.2008.

[4] R. MAYER, L.D. POULIKAKOS, A.R. LEES, K. HEUTSCHI, M.T. KALIVODA, P. SOLTIC: "Reducing the environmental impact of road and rail vehicles". Environmental Impact Assessment Review 32(1), pg. 25-32, 2012.

[5] "SILENCE - Practitioner Handbook for Local Noise Action Plans", http://www.silence-ip.org/, 2008. 